\title{
СИНТЕЗ ПОТЕНЦИАЛЬНЫХ ПРЕПАРАТОВ ДЛЯ ФОТОДИНАМИЧЕСКОЙ ТЕРАПИИ ОНКОЛОГИЧЕСКИХ ЗАБОЛЕВАНИЙ И МИКРОБНЫХ ИНФЕКЦИЙ НА ОСНОВЕ АМФИФИЛЬНЫХ ХЛОРИНОВЫХ КОНЬЮГАТОВ
}

\author{
Д.Р. Каримов', Д.Б. Березин', Н.В. Кукушкина', А.В. Кустов ${ }^{1,2}$, \\ Т.К. Рочева ${ }^{3}$, Д.В. Белых ${ }^{3}$ \\ ${ }^{1}$ НИИ макрогетероциклов, Ивановский государственный химико-технологический \\ университет, 153000, Российская Федерация, Иваново, Шереметевский пр-т, 7. \\ ${ }^{2}$ Объединенный физико-химический центр растворов, Институт химии растворов \\ им. Г.А. Крестова РАН, 153045, Российская Федерация, Иваново, ул. Академическая, 1. \\ ${ }^{3}$ Институт химии ФИЦ Коми научного центра Уральского отделения РАН, \\ 167000, Российская Федерация, Республика Коми, Сыктывкар, ул. Первомайская, 48.
}

DOI: 10.19163/MedChemRussia2021-2021-515_E-mail:berezin@isuct.ru

Фотодинамическая терапия (ФДТ) является перспективным малоинвазивным методом лечения онкологических заболеваний, а также эффективным способом борьбы с патогенными микроорганизмами, к которому не вырабатывается резистентности [1, 2]. ФТД предполагает использование окрашенных веществ - фотосенсибилизаторов (ФС), способных избирательно накапливаться в клетках опухолей или микроорганизмов и при облучении светом определённой длины волны приводить к их гибели, не затрагивая здоровые клетки. К потенциальным ФС выдвигается ряд требований: амфифильность, эффективная генерация активных форм кислорода при облучении в красной или ближней ИК-области спектра, высокая избирательность накопления в атипичных клетках, низкая токсичность и фототоксичность в отношении здоровых тканей и т.д. Перспективными и доступными соединениями для целей ФДТ являются производные хлорина е продукты химической модификации хлорофилла $а$. При создании новых ФС приветствуется их многоцелевое использование, например, сочетание диагностического и различных терапевтических (как за счет их фото-, так и темновой цитотоксичности) подходов. Желаемый тераностический эффект может быть достигнут при химическом связывании хлоринового ФС с фрагментами препаратов антимикробного или противоопухолевого действия («Диоксидин», «Мирамистин» и др.) [2, 3]. Активный целевой транспорт ФС в малигнизированные клетки может реализовываться за счет конъюгирования хлорина е6 с некоторыми природными аминокислотами и сахарами [1], а растворимость в воде и биологических жидкостях - при введении в молекулу ФС гидрофильных групп [4]. Предложенные синтетические подходы рассматриваются в настоящем докладе.

Исследование выполнено за счет гранта Российского научного фонда № 21-13-00398.

\section{Литература}

[1] А.В. Кустов, Д.Б. Березин и др., Противоопухолевая и антимикробная фотодинамическая терапия: механизмы, мишени, клинико-лабораторные исследования. Москва: Ларго, 2020.108 c.

[2] O.I. Koifman, T.A. Ageeva, I.P. Beletskaya, et al., Macroheterocycles, 2020.13(4), 311-467.

[3] A.V. Kustov, T.V. Kustova, D.V. Belykh, I.S. Khudyaeva and D.B. Berezin, Dyes Pigments, 2020, 173, 107948.

[4] C. Giancola, M. Caterino, F. D’Aria, A.V. Kustov et al. Intern. J. Biol. Macromol., 2020, 145, 244-251. 